\title{
Description of a new species of Ituglanis (Siluriformes: Trichomycteridae) from Serra dos Carajás, rio Tocantins basin
}

\author{
Wolmar B. Wosiacki ${ }^{1}$, Guilherme M. Dutra² and Marina B. Mendonça²
}

A new species of Ituglanis is described from the rio Tocantins basin, State of Pará, Brazil. Ituglanis ina, new species, is distinguished from its congeners by the presence of a dark vertical bar over the base of the caudal-fin rays (vs. no bars over caudal-fin base); and by the presence of a middle trunk line of tiny neuromasts extending along the flank until the vertical through the dorsal fin, or near the caudal-fin base (vs. no middle trunk line of tiny neuromasts). Ituglanis ina can be further distinguished by a combination of characters related to color pattern and morphology. Comments on the relationship between Ituglanis species are presented.

Uma espécie nova de Ituglanis é descrita da bacia do rio Tocantins, Pará, Brasil. Ituglanis ina, espécie nova, é facilmente diferenciada das congêneres por apresentar uma barra vertical escura sobre a base dos raios da nadadeira caudal (vs. sem barras na base da nadadeira caudal); e por apresentar linha lateral seguida por uma linha de diminutos neuromastos até a região do flanco, abaixo da nadadeira dorsal, ou até o pedúnculo caudal (vs. sem neuromastos após a linha lateral). Ituglanis ina distingue-se, também, por uma combinação de caracteres relacionados ao padrão de coloração e morfologia. Comentários sobre o relacionamento das espécies e grupos de espécies de Ituglanis são apresentados.

Key words: Color pattern, East Amazon, Fresh water, Neotropical catfish, Ostariophysi.

\section{Introduction}

Ituglanis was proposed by Costa \& Bockmann (1993) to include nine species previously allocated in Trichomycterus (Trichomycterinae), distributed throughout the middle and lower rio Amazonas and rios Tocantins, São Francisco, Paraná, and Paraguay drainages, and on the southern and southeastern Brazilian coast (de Pinna \& Wosiacki, 2003). The species of Ituglanis inhabit small streams and rapids, and include a few troglomorphic forms (Bichuette \& Trajano, 2004, 2008).

Initially, Costa \& Bockmann (1993) proposed Ituglanis as sister group to a clade composed by Vandelliinae, Stegophilinae, Tridentinae, Glanapterygiinae, and Sarcoglanidinae (VSTGS), a hypothesis also accepted by de Pinna (1998). Wosiacki (2002), in a slightly different hypothesis, proposed Scleronema as sister group of the VSTGS assemblage and Ituglanis as sister group to Scleronema plus VSTGS. Interspecific relationships of this genus are still unknown.

In the present study, we describe a new species of Ituglanis based on specimens from the Serra dos Carajás, rio Tocantins basin, State of Pará, Brazil, and discuss hypothesis of relationships among groups of species of this genus.

\section{Material and Methods}

All measurements were taken point-to-point with calipers on the left side of the specimens. Caudal peduncle length was measured from the base of the last anal-fin ray to the middle of the caudal-fin base; caudal peduncle depth was taken at the vertical through the middle of its length. Remaining measurements followed Tchernavin (1944). Dorsal and anal-fin ray counts included all branched rays (Arabic numerals) plus all unbranched rays (small Roman numerals) visible under a stereomicroscope. An asterisk indicates counts for the holotype. Frequency is presented in brackets. Specimens cleared and counterstained (c\&s) for cartilage and bone were prepared according to Dingerkus \& Uhler (1977). Numbers of vertebrae and pleural ribs were taken from c\&s specimens. Vertebral counts in c\&s specimens did not include those in the Weberian complex and compound caudal centrum. The caudal skeleton follows Lundberg \& Baskin (1969) notation. The nomenclature for the laterosensory canal system and associated pores follows Arratia \& Huaquin (1995); tiny neuromasts are numbered as small Roman numerals. Institutional abbreviations follow

\footnotetext{
${ }^{1}$ Museu Paraense Emílio Goeldi, Caixa Postal 399, 66040-170 Belém, PA, Brazil. wolmar@museu-goeldi.br ${ }^{2}$ Universidade Federal do Pará, Museu Paraense Emílio Goeldi, Programa de Pós-Graduação em Zoologia. guilhermedutr@yahoo.com.br (GMD), barreira.mm@gmail.com (MBM)
} 
Ferraris (2007). Description of the color pattern, in recently fixed specimens, was based on photography.

\section{Ituglanis ina, new species}

Figs. 1-3

Holotype. MPEG 19613, 62.0 mm SL, Brazil, Pará, Parauapebas, Serra dos Carajás, tributary of the left bank of rio Parauapebas, tributary of the right bank of rio Itacaiúnas, tributary of the right bank of rio Tocantins, $06^{\circ} 06^{\prime} 2.8^{\prime \prime}$ S 5008'11.9”W, 20 Sep 2009, M. B. Mendonça \& T. M. S. Freitas.

Paratypes. Same data as holotype, except when noticed: MPEG 17383, 6, 11.8-42.0 mm SL, 0605’15.6”S 5007’56.9”W, 21 Sep 2009; MPEG 17384, 4, 11.5-61.5 mm SL, 0606’13.5”S 5007'58.6”'W, 22 Sep 2009; MPEG 17385, 10, 12.5-42.5 mm SL, 0606'13,5”S 5007’58,6”'W, 22 Sep 2009; MPEG 17386, 12, 29.852.0 mm SL (5 c\&s, 30.5-51.2 mm SL), 0605'15.6”S 5007'56.9”'W, 21 Sep. 2009; MPEG 17387, 54.9 mm SL; MPEG 17388, 16, 18.3$59.9 \mathrm{~mm} \mathrm{SL}$; MNRJ 38989, 2, 37.7-53.8 mm SL, same data as MPEG 17384; INPA 35416, 2, 37.4-49.2 mm SL, same data as MPEG 17386.

Diagnosis. Ituglanis ina is distinguished from all congeners by the presence of a vertical dark bar on the base of the caudal-fin rays ( $v s$. absence), and by the lateral line (LL1 and LL2, rarely LL3) followed by a middle trunk line composed of 1-30 tiny neuromasts, extending to flank, below the dorsal fin or, at times, to caudal peduncle near the caudal-fin base, in all specimens larger than $35.0 \mathrm{~mm}$ SL (vs. tiny neuromasts absent). Ituglanis ina can be further distinguished from all congeners (except Ituglanis parkoi) by general body color gray, dark on the dorsal region and gradually pale ventrally, without spots or longitudinal stripes (vs. no general gray color, with spots or longitudinal stripes). Ituglanis ina can be distinguished from I. parkoi by the fewer opercular odontodes, 10-12 (vs. 22); and by the caudal-fin margin circular with attenuated edges (vs. truncated).

Description. Morphometric data presented in Table 1. Body elongate, approximately cylindrical near head, gradually compressed toward caudal peduncle. Dorsal profile of body straight from margin of upper lip to supraoccipital, convex from that point to transverse line that passes at middle of pectoral-ray length, straight to dorsal-fin origin, and slightly concave between dorsal-fin origin and tip of caudal peduncle. Ventral profile of body convex from lower lip to transverse line through middle of interopercle, concave from that point to transverse line that passes at middle of pectoral-fin ray length, slightly convex to anal-fin origin, concave at anal-fin base, and straight to slightly concave from insertion of last anal-fin ray to base of ventral caudal-fin rays. Skin thick, especially on dorsal, anal and pectoral-fin bases.

Head longer than wide, depressed, trapezoidal in dorsal view, wider at posterior edge of opercle than between bases of maxillary barbel, anterior margin of snout slightly rounded. Region between eyes and lateral margin of head with hypertrophied and obvious adductor mandibulae muscle, in juvenile and adult specimens.

Eye round, margin not well defined, dorsally oriented, covered by thin skin in contact with lens; ocular structure visible on cutaneous surface; orbital margin not free.

Anterior nostril surrounded antero-mesially by thin fold of skin, and postero-laterally by fleshy and thick base of nasal barbel, diameter distinctly greater than posterior nostril. Posterior nostril approximately circular, same diameter as eye, occluded anteriorly by fleshy integument shaped like a half-shell.

Branchial membrane thick, united anteriorly to isthmus, forming small transverse skin fold. Gill opening relatively wide. Branchiostegal rays 8-10 (visible in c\&s specimens), 4-7* externally visible. Mouth subterminal, corners directed laterally. Upper lip posteriorly continuous with head surface; anterior margin slightly rounded, in dorsal view; papillae on all surface. Lower lip distinctly narrower than upper lip, between two lateral lobes at base of inner rictal barbels; covered by papillae smaller than that on upper lip; anterior margin slightly rounded in ventral view.

Barbels long with wider fleshy bases, becoming gradually

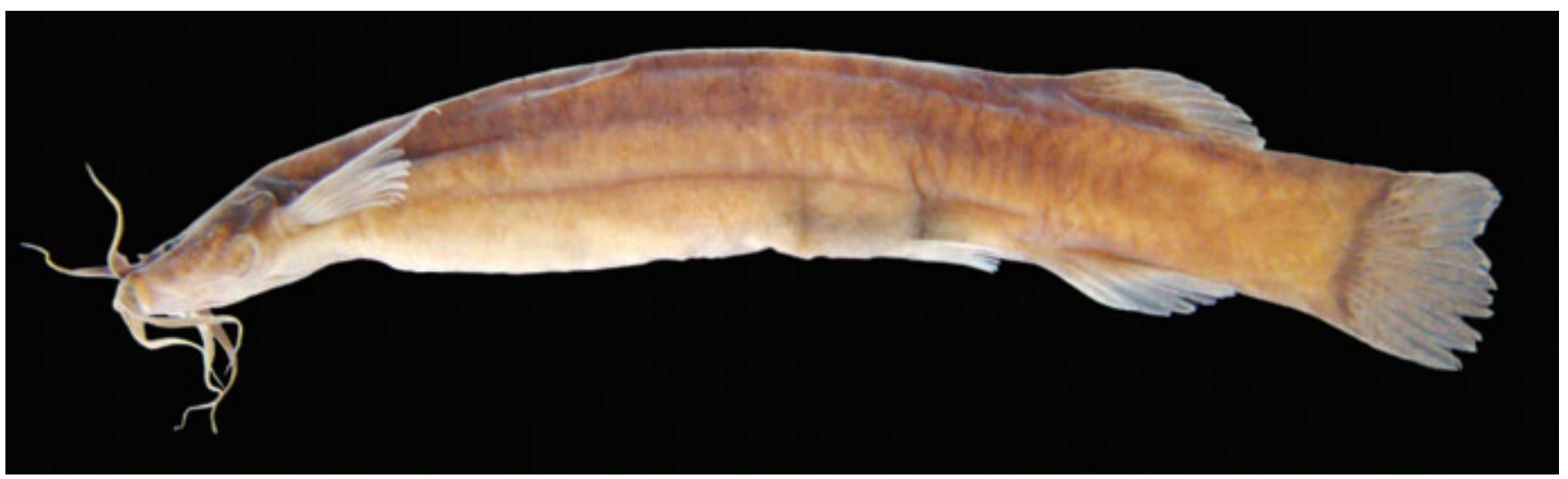

Fig. 1. Ituglanis ina, MPEG 19613, holotype, $62.0 \mathrm{~mm}$ SL, inverted lateral view of the right side; Brazil, Pará, Parauapebas, Serra dos Carajás, tributary of the Parauapebas, tributary of the rio Tocantins. 
Table 1. Morphometric data for the holotype and paratypes of Ituglanis ina ( $\mathrm{n}=54$ including holotype).

\begin{tabular}{|c|c|c|c|c|}
\hline & Holotype & Min. & Max. & Mean \\
\hline Standard length (mm) & 62.0 & 11.5 & 62.0 & - \\
\hline \multicolumn{5}{|c|}{ Percents of standard length } \\
\hline Total length & 113.6 & 112.3 & 127.6 & 118.8 \\
\hline Body depth & 15.4 & 11.7 & 17.0 & 14.0 \\
\hline Peduncle length & 16.1 & 12.7 & 21.5 & 17.7 \\
\hline Peduncle depth & 12.7 & 9.9 & 13.6 & 11.9 \\
\hline Predorsal length & 74.8 & 70.1 & 76.8 & 73.3 \\
\hline Preanal length & 74.2 & 70.0 & 78.8 & 73.6 \\
\hline Prepelvic length & 63.6 & 52.2 & 67.3 & 63.4 \\
\hline Dorsal-fin base length & 9.5 & 8.2 & 13.2 & 10.3 \\
\hline Anal-fin base length & 7.1 & 6.9 & 12.6 & 8.8 \\
\hline Head length & 17.8 & 17.0 & 24.3 & 19.8 \\
\hline \multicolumn{5}{|c|}{ Percents of head length } \\
\hline Head width & 79.5 & 77.2 & 98.2 & 86.0 \\
\hline Head depth & 43.1 & 38.7 & 53.3 & 45.3 \\
\hline Interorbital distance & 26.4 & 19.0 & 32.1 & 27.0 \\
\hline Snout length & 40.2 & 31.1 & 42.1 & 36.3 \\
\hline Nasal barbel length & 86.6 & 72.3 & 101.8 & 84.2 \\
\hline Maxillary barbel length & 105.3 & 85.4 & 126.2 & 101.6 \\
\hline Rictal barbel length & 80.5 & 67.4 & 94.7 & 80.1 \\
\hline Mouth width & 42.7 & 31.8 & 49.8 & 38.8 \\
\hline Eye diameter & 7.5 & 6.5 & 13.6 & 9.8 \\
\hline
\end{tabular}

narrow toward tips. Nasal-barbel origin at posterior-lateral region of anterior nostril; distal portion reaching half opercle (5), posterior margin of opercle (24) or pectoral-fin origin (25*). Maxillary barbel reaching pectoral-fin origin (15) or surpassing that point (39*). Rictal barbel reaching margin of gill membrane (3), pectoral-fin origin (49*) or surpassing that point (2).

Interopercular patch of odontodes long, latero-ventrally oriented, 19-20* (21-25 in c\&s), conical odontodes arranged in two irregular rows (antero-dorsal and postero-ventral), covered with thick integument, especially on posterior margin, with minute papillae; odontodes from antero-dorsal row smaller and straight, odontodes from postero-ventral row longer and slightly curved medially. Opercular patch of odontodes round, latero-dorsally oriented, $10,11 *$ or 12 (16 in c\&s) conical odontodes arranged irregularly, partially covered by thick skin, mainly posterior; anteriormost odontodes smaller; posterior ones gradually larger and slightly curved medially.

Lateral line sensory canal including supraorbital branch, S1, S3, S6 (40*), or S3 and S6 (2), two opposite pores S6; incomplete infraorbital branch, I10, I11 (40*) or I11 (2); preopercular, Po1, Po2 (41); branch of lateral line, LL1 and LL2 (53*), rarely LL3 (2), tiny neuromasts of middle trunk line (40, specimens larger than $35.0 \mathrm{~mm} \mathrm{SL}$ ), i(3), ii(1), iii (2), v (1), ix (5), x (2), xi(1), xii (2), xiv (1), xvi(1), xvii (2), xviii (2), xix (3), xx (1*), xxi (2), xxii (1), xxiii (3), xxiv (1), xxv (2), xxvii (1), or xxx (3).

Pectoral fin trapezoidal, distal margin slightly circular, i,5 (48*) or i,6 (6) rays, first ray inserted immediately below posterior margin of opercle, extending beyond margin as filament. Dorsal fin semicircular, i,6 (1), i,7 (3), ii,5(3), ii,6(19*), ii,7 (19), iii,5(1) or iii,6 (7) rays, second or third ray not branched and first branched ray longer than others. Anal fin semicircular, slightly shorter

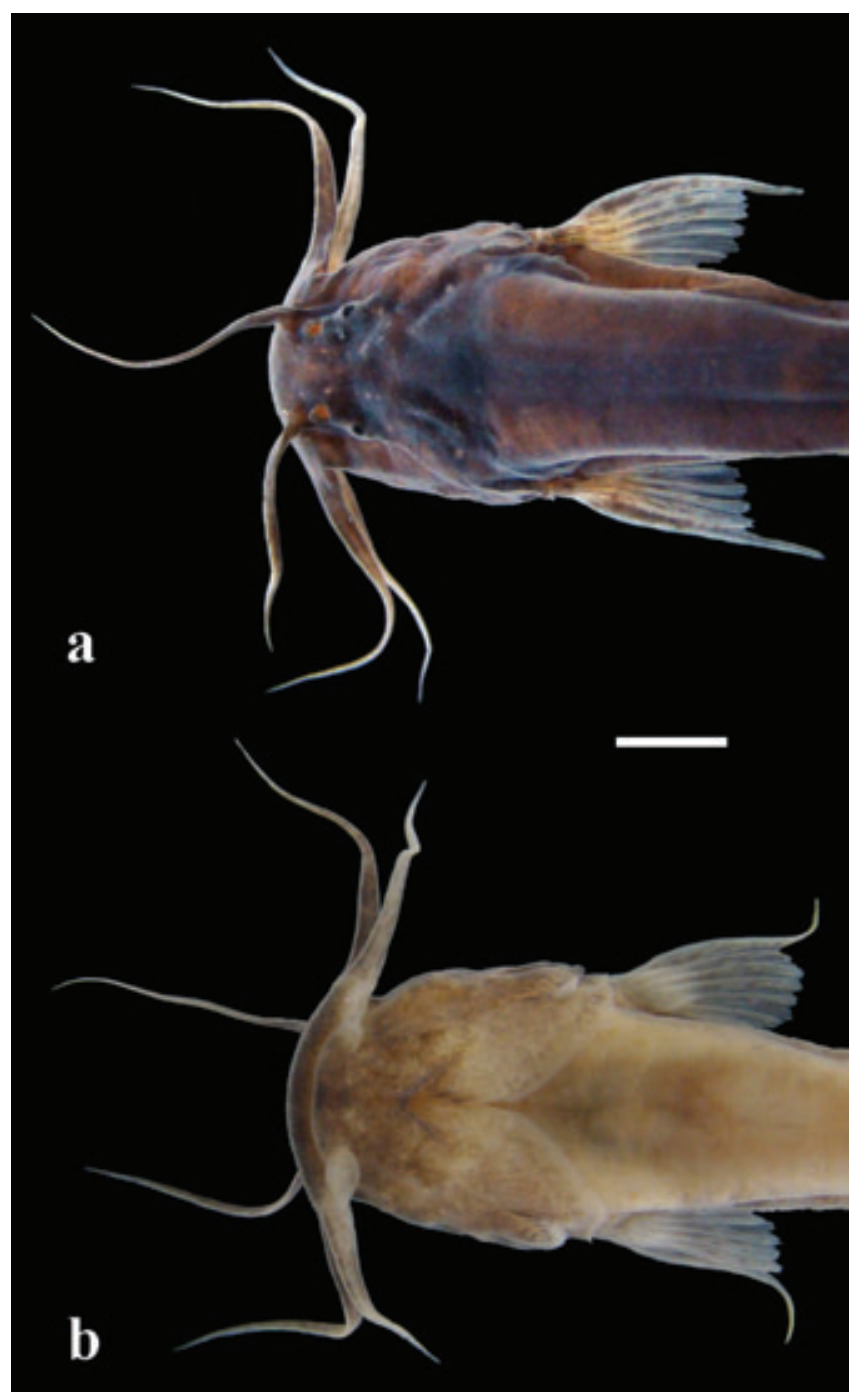

Fig. 2. Ituglanis ina, MPEG 19613, holotype; (a) dorsal and (b) ventral view of the head. Scale bar $=5 \mathrm{~mm}$.

than dorsal fin, origin on transversal line at base of first branched dorsal-fin ray, i,5 (1), i,6 (2), ii,4 (2) ii,5 (42*), ii,6 (2), iii,4 (2), or iii,5 (2) rays, last ray not branched and first two branched ones longer than others. Pelvic fin roughly rectangular, distal margin circular, anterior to dorsal-fin origin, completely covering urogenital opening, not reaching analfin origin (rarely, 2 ex.), i,2 (1), i,3 (25), or i,4 (28*) rays, second and third longer than others, base of medial rays of opposite fins close but not in contact. Caudal margin with circular edges and rounded borders, when expanded distally higher than at base of rays, i,5/6,i (4), i,5/5,ii (8), ii,3/5,ii (1), ii,4/5,i (1), ii,4/6,i (6), ii,4/5,ii (29*), ii,4/6,ii (1), ii,5/4,ii (2), or ii,5/5,ii (2), dorsal and ventral outer rays not branched, branched rays branching twice, but only in juveniles exclusively in central rays. Dorsalprocurrent rays 5-11* externally visible in specimens preserved in ethanol (15-19 in c\&s), posterior ones long, gradually becoming short anteriorly. Ventral-procurrent rays 13-14 (visible in c\&s specimens), 5-7* externally visible, 
posterior ones long, gradually becoming short anteriorly. Anal and urogenital openings at half distance between pelvic-fin base and anal-fin origin.

Free vertebrae 38-40. Precaudal vertebrae 17-19. Abdominal vertebrae 14-17. Caudal vertebrae 20-22. Ribs 2 or 3 pairs, first and second thickest, third thinner or absent. Dorsal-fin pterygiophores 7-8, first pterygiophore inserting anterior to neural spine of $24^{\text {th }}$ or $25^{\text {th }}$ free vertebrae. Anal pterygiophores 6 , first pterygiophore anterior to hemal spine of $23^{\text {rd }}$ to $25^{\text {th }}$ free vertebrae. None (3) or one (2) vertebrae between first dorsal-fin pterygiophore and first anal-fin pterygiophore. Caudal skeleton pleurostyle, fused parahypural and hypurals $1+2 ; 3 ; 4+5$ or $3+4+5$.

Color in recently fixed individuals. General color gray on ground color light brown, darker on dorsal and anal-fin bases, and over dorsal midline region of head, trunk, and caudal peduncle. Gradually clearer ventrally. Abdomen white. Vertical bar over base of the caudal-fin rays, distinctly thicker and darker on the central rays. Dorsal, anal and caudal fins with tiny chromatophores scattered just over rays, larger and more evident on caudal fin.

Color in ethanol. Ground color usually light cream. Superficially, light brown pigmented, similar in small and large specimens (Fig. 3); darker on dorsal midline region of head, trunk and caudal peduncle, gradually clearer ventrally. Region between eye, opercle and interopercle slightly pale, similar to region immediately lateral to eye (cheek). Upper and lower lips gray; lower lip distinctly clearer than upper lip, slightly dark in medial region. Nasal and maxillary barbels with dark gray bases, gradually light distally, until light cream color tips; maxillary barbel darker on dorsal surface than on ventral one. Rictal barbel paler than nasal and maxillary barbels, with dark gray base, gradually light distally; darker on dorsal surface than on ventral one. Rictal lobes pale, with small scattered chromatophores. Region between rictal lobes light gray, gradually light posteriorly, toward isthmus. Ventrolateral region of head light gray, gradually light medially, with sparse chromatophores forming small patches on gill membrane in medial region. Abdomen light cream, sometimes gray over posterior half. Fins pale; dorsal fin densely pigmented over thick skin on base of rays, tiny chromatophores scattered only over rays, translucent margin; anal fin similar to dorsal fin but slightly lighter; pectoral fin white, with tiny chromatophores only on rays, denser at base and over outer unbranched ray, gradually more scattered towards the margin completely translucent, ventral surface slightly lighter than dorsal surface; pelvic fin with few chromatophores only at base of rays of dorsal surface, denser on outer ray, ventral surface without or with few chromatophores at base of unbranched ray; caudal fin slightly darker than other fins, with chromatophores only on rays, dense at base, gradually sparse and small distally, toward completely translucent margin. Discreet, but distinct, vertical dark bar over base of caudal-fin rays from dorsal to ventral fold margins, distinctly thicker and darker on the central rays.
Geographic distribution. Ituglanis ina is known from tributaries of rio Parauapebas, a tributary of the rio Itacaiúnas, which is in turn a tributary of the right bank of the rio Tocantins, Serra dos Carajás, State of Pará, Brazil (Fig. 4).

Etymology. The specific epithet "ina" is in reference to the term "inã", which means person, a self-designation of the Karajás (Carajás) indigenous people that inhabit the Serra dos Carajás. Macro-Gê linguistic trunk, Carajás linguistic family. A noun in apposition.

\section{Discussion}

Costa \& Bockmann (1993) proposed the genus Ituglanis as a natural group and showed evidence that it is related to the more derived trichomycterids than to species allocated in the genus Trichomycterus. Recent contributions (Fernández \& Bichuette, 2002; Wosiacki, 2002; de Pinna \& Keith, 2003; Bichuette \& Trajano, 2004, 2008; Datovo \& Landim, 2005; Sarmento-Soares et al., 2006; Campos-Paiva \& Costa, 2007) significantly increased the taxonomic and systematic knowledge of the group, corroborating the initial hypothesis that the genus is monophyletic.

As synapomorphies for Ituglanis, Costa \& Bockmann (1993) proposed fontanel reduced to a small circular orifice on the supraoccipital, palatine with a deep medial concavity, and anterior portion of sphenotic directed anteriorly. Wosiacki (2002) observed that I. amazonicus, I. eichorniarum, I. proops, and an undescribed species of this genus share the parapophysis of the first four free vertebrae directed medially. In the basal Trichomycteridae, these parapophysis are laterally directed downward. Wosiacki (2002) noted that these same species mentioned above share the presence of five or more abdominal vertebrae and represent a derived state of the presence of four or fewer abdominal vertebrae as observed in Callichthys (2), Nematogenys (4), Copionodontinae (1), and Trichogenes (2). In addition, Wosiacki (2002) observed another two characters, not exclusive, shared for species of Ituglanis, including I. ina: 1) the presence of two or fewer vertebrae between the first pterygiophore of the dorsal fin and the first pterygiophore of the anal fin, shared as convergence in some Glanapteryginae and Vandelliinae; and 2) the presence of 23 or more free vertebrae anterior to the first pterygiophore of the dorsal fin, shared as convergence in some Glanapteryginae, Stegophilinae, and Vandelliinae.

All synapomorphies of Ituglanis proposed by Costa \& Bockmann (1993) and Wosiacki (2002) are present in Ituglanis ina. More recent studies (Bichuette \& Trajano, 2008; Datovo \& Landim, 2005; Sarmento-Soares et al., 2006; de CamposPaiva \& Costa, 2007) indicate that the fontanel reduced to a small circular orifice on the supraoccipital is a derived character, exclusive to the group, and not shared by any other species or group of Trichomycteridae. A vaguely similar condition is observed in species of Aspidoras (Callichthyidae), where the foramen of the supraoccipital is 


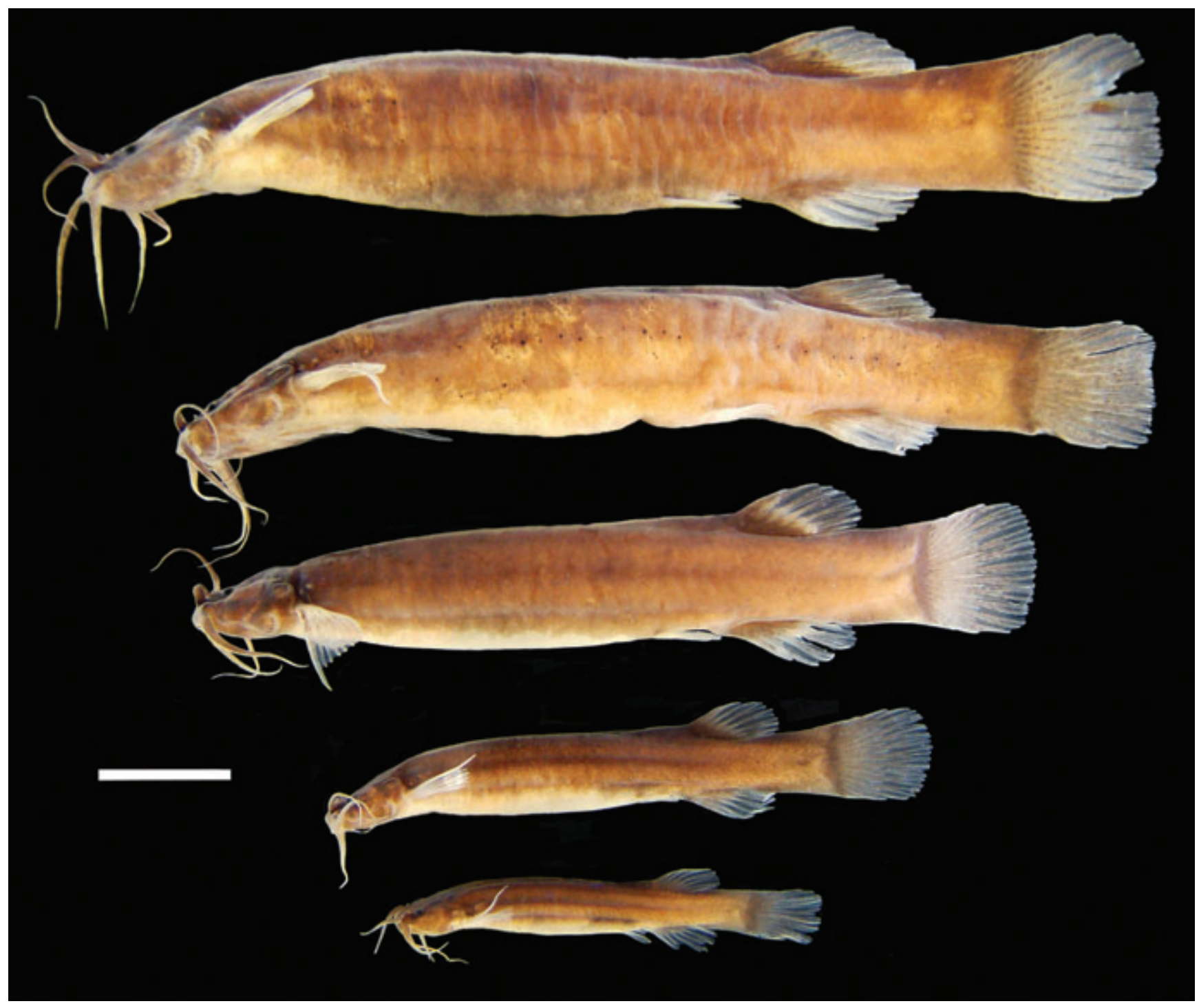

Fig. 3. Ituglanis ina, paratypes, MPEG 17388. Left lateral view showing the gray color pattern and the vertical dark bar on the base of the caudal-fin rays, in large to small specimens. Black spots over body are nematodes’ cysts. Scale bar $=1 \mathrm{~cm}$.

reduced. However, the two states are parsimoniously interpreted as convergent.

De Pinna \& Keith (2003) proposed a group of species (Ituglanis nebulosus, I. gracilior, I. amazonicus, and "Ituglanis sp. 2"), that later also came to include I. macunaima according to Datovo \& Landim (2005), that share an extreme reduction in the number of ribs (three or fewer). This character is also shared by I. ina, which therefore should also be included in that group. De Pinna \& Keith (2003) also proposed a second, more inclusive, clade (I. nebulosus, I. amazonicus, and "Ituglanis sp. 2") where the main body of the mesethmoid is distinctly wider. The latter condition is not shared by I. ina which has a slender mesethmoid, so its relationship remains uncertain.

Some records of Trichomycteridae species from rio Tocantins basin, area of occurrence of Ituglanis ina, are Ammoglanis diaphanus (de Pinna \& Wosiacki, 2003), I. amazonicus (Steindachner, 1882), I. passensis (Fernández \& Bichuette, 2002), I. macunaima (Datovo \& Landim, 2005), I. mambai (Bichuette \& Trajano, 2008), Henonemus intemedius, Trichomycterus punctatissimus, Tridentopsis tocantinsi, and Typhlobelus macromycterus (de Pinna \& Wosiacki, 2003).

Ituglanis ina is easily distinguished from the more derived trichomycterids mentioned above (A. diaphanus, $H$. intemedius, Tridentopsis tocantinsi and Typhlobelus macromycterus) by not sharing the synapomorphies for clade 5 in de Pinna (1998).

The exact distribution of T. punctatissimus is unknown, and is based on data provided for the holotype cited as coming from "De l'Araguay" by Castelnau (1855), and as “Araguaia - Cours d'eau: Araguaia “ on the MNHN homepage (http:// coldb.mnhn.fr/colweb/request.do?requestaction=exec accessed 1 march 2012). However, analysis of images of the 


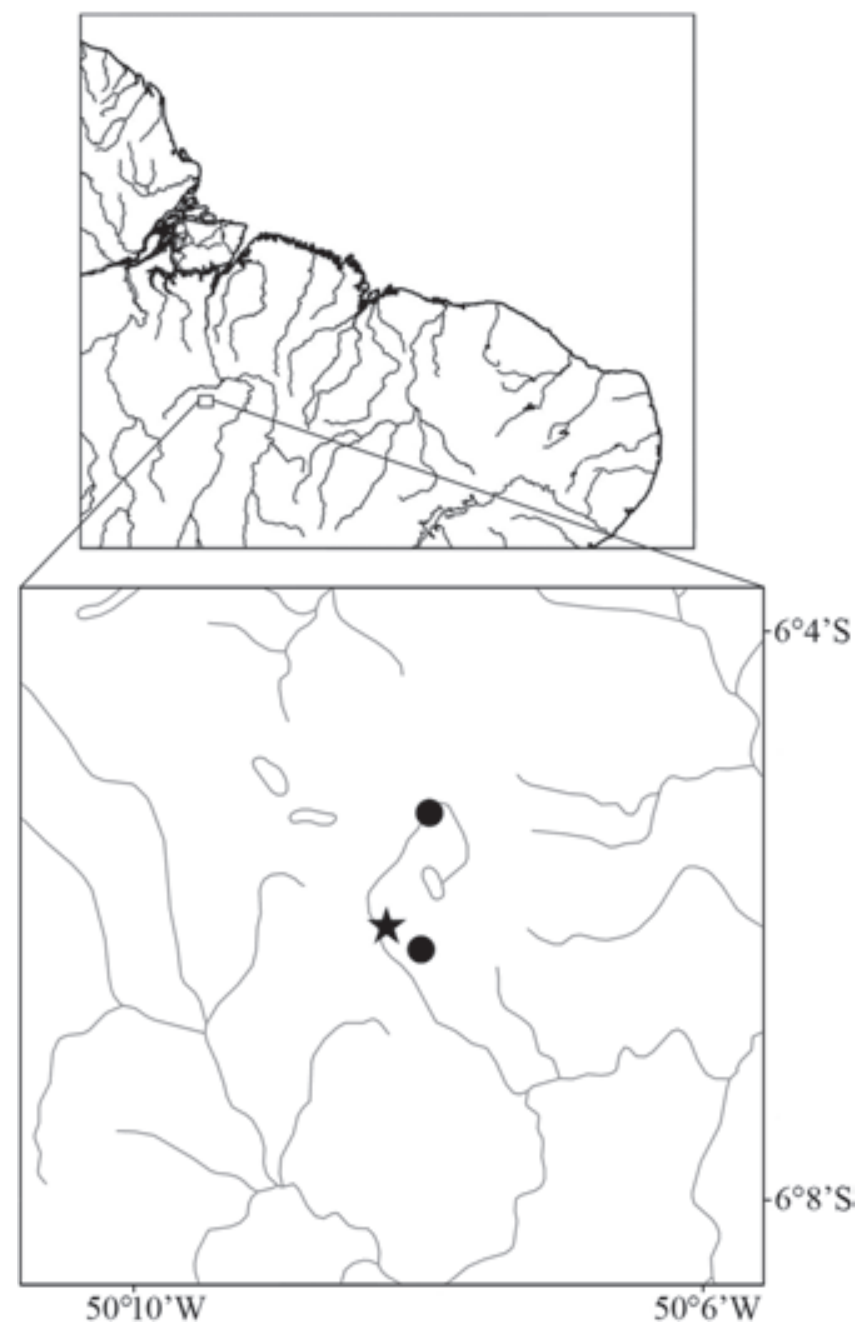

Fig. 4. Map of part of the northern and northeastern South America showing the distribution of Ituglanis ina. Star represents the type locality.

holotype of $T$. punctatissimus, available on the same homepage made it possible to easily distinguish the different species. It is possible to observe, in the radiograph of $T$. punctatissimus, four free vertebrae between the first dorsalfin pterygiophore and the first anal-fin pterygiophore, distinct from the zero or one observed in I. ina. Although 155 years have passed since it was collected, the holotype of $T$. punctatissimus is in relatively good condition, and it is easy to observe the position of the anal-fin origin under the second to last ray of the dorsal fin, which is very different from that of I. ina in which the origin is over the first or second dorsal-fin ray. The gray color pattern, observed in I. ina, dark on the dorsal region and becoming gradually light toward the ventral region, distinguishes it easily from $T$. puctatissimus, as shown in the drawing by Castelnau (1855) and still partially observed in the holotype, which has a dark dorsal and dorso-lateral region that becomes abruptly pale in the ventral and ventrolateral region. The gray color pattern throughout the body of
Ituglanis ina is shared only by its congener, I. parkoi. This character distinguishes it easily from the congeners $I$. amazonicus, I. macunaima, I. mambai, and I. passensis that have a vaguely similar distribution but very different coloration pattern: I. passensis is pale yellow with melanophores restricted to the dorsal region, whilst $I$. amazonicus, $I$. macunaima, and I. mambai share a pale yellow color with light brown spots. The degree of phylogenetic relationships between I. ina and I. parkoi are unknown, hindering the understanding of the emergence of the gray color pattern. However, both species are easily differentiated from one another by the shape of the caudal-fin margin which in I. ina is round with attenuated edges, while in I. parkoi it is distinctly truncate. The gray color pattern is shared, among trichomycterines, with $T$. immaculatus, $T$. trefauti, $T$. taczanowskii, T. kneri, T. plumbeus, and T. papilliferus. The lack of knowledge about the relationships between these species does not allow us to affirm if there is a phylogenetic signal in the gray color. This color pattern is not shared with other species of Trichomycteridae (except for Glaphyropoma rodriguesi; Copionodontinae), nor Nematogenis inermis (Nematogenyidae), sister group of Trichomycteridae.

Silva et al. (2010) observed that young specimens (30.9 $\mathrm{mm}$ SL) of Trichomycterus iheringi have a light ground color, with large blotches on the back and flanks that gradually decrease in size and increase in number in larger specimens, showing that color pattern may have notable ontogenetic variation. Arratia et al. (1978) reported variation in the color pattern of Trichomycterus mendozensis (= Silvinichthys mendozensis) related to the type of substrate. The variation observed by Silva et al. (2010) and Arratia et al. (1978) does not occur in Ituglanis ina where the color pattern is gray, darker on the back, with a bar on the base of the caudal-fin rays, without the presence of spots or lines in the entire size range (11.51 to $61.96 \mathrm{~mm} \mathrm{SL}$ ) (Fig. 3).

The presence of a dark bar across the base of the caudalfin rays of Ituglanis ina is unusual in Trichomycteridae (Wosiacki, 2004) and is only shared with Trichomycterus trefauti. In both species, the bar is present in individuals of all sizes (Fig. 3; Wosiacki, 2004), demonstrating that this is an ontogenetically stable character. The presence of a dark bar, in both species, is not homologous, since T. trefauti does not share any of the characteristics considered synapomorphies for Ituglanis, nor the features shared by Ituglanis and the VSTGS group (sensu Costa \& Bockmann, 1993).

The laterosensory canal system in Trichomycteridae, exclusive of Trichogenes and Copionodontinae, shows various degrees of reduction, such as the incomplete infraorbital series (de Pinna, 1998), restricted mainly to pores I10 and I11, or its total absence. Also, a severe reduction in the number of lateral line pores is present, restricted only to pores LLI, LL2, or LL3. Some exceptions can be observed in the trichomycterines Hatcheria, Bullockia, Trichomycterus crassicaudatus, and T. igobi that display four to seven pores. Also, some genera of Stegophilinae present a long lateral line extending to the caudal peduncle, as in Stegophilus, or until the base of the caudal-fin 
rays, as in Pareiodon and Pseudostegophilus. The lateral line in Ituglanis ina is reduced to two, rarely three, pores, as in the congeners, followed by a variable number (1-30) of tiny aligned neuromasts, extending along the midlateral line of the body, not present in the congeners, and hypothesized as an autapomorphy. Apparently this condition is related to the ontogenetic development, since it has been observed only in specimens larger than $35.0 \mathrm{~mm}$ SL. However, it is a condition shared with Silvinichthys mendozensis, described by Arratia (1998), in which the lateral line is reduced to two pores, followed by tiny aligned neuromasts, not present in all individuals. One difference observed between the two species is that $S$. mendozensis has two series (dorsal and lateral) of tiny neuromasts, while $I$. ina has only one series. The degree of relationships between $I$. ina and species of Silvinichthys are unknown. However, the set of derived characters shared by $I$. ina with other species of Ituglanis, as well as, with the other more derived groups in the family, allows one to estimate that the tiny aligned neuromasts present in S. mendozensis and $I$. ina are not homologous.

Comparative material. Bullockia maldonadoi: MZUSP 36958, 1 c\&s, 45.5 mm SL, Chile, Coigüe, rio Bio Bio. Copionodon pecten: MZUSP 48962, 4 + 3 c\&s, 40.5-51.5 mm SL, Brazil, Bahia, Lençois, rio Lençois, tributary of rio Paraguaçu. Glaphyropoma rodriguesi: MZUSP 42466, 1 c\&s, 51 mm SL, paratype, Brazil, Bahia, Mucujê, rio Mucujê. Hatcheria macraei, MZUSP 35687, 1, 67.4 mm SL, 2 disarticulated c\&s, Argentina, Córdoba, Pilar, río Segundo. Ituglanis amazonicus: MPEG 3345, 1 c\&s, 42.0 mm SL, Brazil, Pará, Parauapebas, igarapé do Pojuca, rio Itacaiúnas, rio Tocantins. Ituglanis eichorniarum: MNRJ 780 A, 33.1 mm SL, Lectotype of Trichomycterus eichorniarum Miranda Ribeiro, 1912, Brazil, Mato Grosso, Cáceres, rio Paraguai. MNRJ 780 B, 24.2 mm SL, Paralectotype of Trichomycterus eichorniarum Miranda Ribeiro, 1912, Mato Grosso, Cáceres, rio Paraguai. Ituglanis gracilior: FMNH 53264, 17.0 mm SL, holotype of Pygidium gracilior Eigenmann 1912, Guiana, Erukin. Trichomycterus guianensis: FMNH 52676, 64.2 mm SL, holotype of Pygidium guianensis Eigenmann, 1909, Guiana, Aruataima Falls, upper rio Potamoro. Ituglanis laticeps: CAS 32458, 1, 66.8 mm SL, Ecuador, Imbabura below Parabama. Ituglanis metae: CAS 118214, 1, 76.5 mm SL, Peru, Loreto, Pebas, Cano near Pebas. CAS 124227, 1, 70.9 mm SL, Loreto, Pebas, Cano Del Chancho near Pebas. Ituglanis parahybae: FMNH 58576, 27.8 mm SL, holotype of Pygidium proops parahybae Eigenmann, 1918, Brazil, Rio de Janeiro, São João da Barra, rio Paraíba. Ituglanis parkoi: MNRJ 3849, 143.0 mm SL, holotype of Pygidium parkoi Miranda Ribeiro, 1944, Brazil, Amazonas, Benjamin Constant, rio Iticoaí. Ituglanis proops: MNRJ 781B, 49.4-63.1 mm SL, 3 paralectotypes of Trichomycterus proops Miranda Ribeiro, 1908, Brazil, São Paulo, Iguape, rio Ribeira do Iguape. Ituglanis sp.: MNRJ 11489, 2, 52.4-60.9 mm SL, c\&s, Brazil, Goiás, Minaçu, córrego Pontilhão. Pseudostegophilus sp.: MPEG 3315, 103.7 mm SL, Brazil, Rondônia, rio Madeira, Boca do Aripuanã. Stegophilus sp.: MPEG 3749, 48.6 mm SL, Brazil, Pará, Belém, Igarapé Tucunduba. Trichogenes longipinnis: MZUSP 63478, 12 + 3 c\&s, 36.7-57.7 mm SL, Brazil, São Paulo, Ubatuba, Cachoeira da Piscina do Amor. Trichomycterus albinotatus: MZUSP 35817, 2, 43.0-44.0 mm SL, Brazil, Rio de Janeiro, Visconde de Mauá, rio Preto, Cachoeira da Maromba. Trichomycterus alternatus: FMNH 58082, $66.1 \mathrm{~mm}$ SL, holotype of Pygidium alternatum
Eigenmann, 1917, Brazil, rio Doce. FMNH 58083, 31.6-59.1 mm SL, 12 paratypes of Pygidium alternatum Eigenmann, 1917, rio Doce. Trichomycterus areolatus: CAS 15649, 8, 66.9-95.5 mm SL, Chile, Los Lagos, río Petrohue. Trichomycterus bahianus: MZUSP 38636, 1 paratype c\&s, 50.7 mm SL, Brazil, Bahia, Una, Ribeirão Caveira. Trichomycterus brasiliensis: MZUSP 37145, 2, 62.4-71.2 mm SL, Brazil, Minas Gerais, Nova Lima, riacho afluente do córrego Mutuca. Trichomycterus castroi: MHNCI 7643, 1, 120.6 mm SL (1 c\&s disarticulated), Brazil, Paraná, Pinhão, foz do córrego da Divisa. Trichomycterus chiltoni: CAS 57596, 149.0 mm SL, holotype of Pygidium chiltoni Eigenmann, 1928, Chile, Bio Bio, Concepcion, río Andalien. CAS 57597, 40.5-138.0 mm SL, 68 paratypes of Pygidium chiltoni Eigenmann, 1928, Estero Nonguen. Trichomycterus crassicaudatus: MPEG 7931, 1 paratype, 113.0 mm SL, Brazil, Paraná, Foz do Jordão, rio Jordão. MPEG 13057, 1 paratype, 34.1 mm SL, Paraná, Candói, rio Jordão. Trichomycterus davisi: FMNH 60309, 41.7 mm SL, holotype (X-ray) of Pygidium davisi Haseman, 1911, Brazil, Paraná, Serrinha, rio Iguaçu system. Trichomycterus igobi: MPEG 13352, holotype, 90.1 mm SL, Brazil, Paraná, Candói, rio Jordão. MPEG 13353, 2 paratype, 72.4-82.7, Paraná, Candói, rio Sobradinho. Trichomycterus iheringi: CAS 64585, $139.6 \mathrm{~mm}$ SL, holotype of Pygidium iheringi Eigenmann, 1917, Brazil, São Paulo, Santos. CAS 64586, 117.6-128.0 mm SL, 3 paratypes of Pygidium iheringi Eigenmann, 1917, São Paulo, Santos. FMNH 58074, 125.7-134.1 mm SL, 2 paratypes of Pygidium iheringi Eigenmann, 1917, São Paulo, Sapina. Trichomycterus itatiayae: MZUSP 44501, 4, 47.7-82.9 mm SL, c\&s, Brazil, Rio de Janeiro, Resende, Bairro da Serrinha, rio Pomba, tributary of rio Pirapitinga, road to Camping Club do Brasil. Trichomycterus longibarbatus: MZUSP 67915, 3 c\&s, 44.1-56.1 mm SL, Brazil, Espírito Santo, Santa Tereza, Reserva de Nova Lombardia. Trichomycterus mboycy: MPEG 6695, holotype, 125.7 mm SL, Brazil, Paraná, Foz do Jordão, rio Jordão. MPEG 6698, 1 + 1 c\&s paratypes, 68.2-82.3 mm SL, Paraná, Pinhão, Rio dos Touros. Trichomycterus meridae: CAS 147809, 6, 29.4-49.0 mm SL, Venezuela, tributary of río Chama. UMMZ 145374, 5, 74.7-95.6 mm SL, río Alberrigas at Merida. Trichomycterus mimonha: MZUSP 49486, 3, 44.8-102.9 mm SL c\&s, Brazil, São Paulo, Araçariguama, stream tributary of rio Tietê, near MAJ and BP companies. Trichomycterus mirissumba: MZUSP 44500, 3 c\&s, 60.0-83.9 mm SL, Brazil, Rio de Janeiro, Rezende, rio Pomba. Trichomycterus punctulatus: MZUSP 67826 (ROM 51725), 2, 68.3-89.8 mm SL, Peru, Cajamarca, just W of Chilete, río Jequetepeque. Trichomycterus rivulatus: MZUSP 67827 (ROM.ICH 40769), 1 c\&s, 134.3 mm SL, Bolivia, La Paz District, lago Titicaca, less than 500 meters from shore. Trichomycterus stawiarski: NUPELIA J1103, 127.7 mm SL, Brazil, Paraná, Foz do Jordão, Jordão reservoir. Trichomycterus striatus: FMNH 7579, 71.9 mm SL, holotype of Pygidium striatum Meek \& Hildebrand, 1913, Panamá, Darien, Cana, río Cana. FMNH 26660, 1 paratype, 53.9 mm SL, Darien, Cana, rio Cana. FMNH 26661, 66.3 mm SL, 1 paratype of Pygidium striatum Meek \& Hildebrand, 1913, Darien, Cana, río Cana. FMNH 26662, 43.4 mm SL, 1 paratype of Pygidium striatum Meek \& Hildebrand, 1913, Darien, Cana, río Cana. FMNH 55233, 53.8 mm SL, 1 paratype of Pygidium striatum Meek \& Hildebrand, 1913, Darien, Cana, Cana. Trichomycterus taroba: MPEG 6689, holotype, 52.7 mm SL, Brazil, Paraná, Foz do Jordão, Jordão reservoir. MPEG 6690, 15 paratypes, 30.7-58.7 mm SL, Paraná, Foz do Jordão, Jordão reservoir. Trichomycterus triguttatus: MZUSP 44543, 3, 52.1-77.7 mm SL, c\&s, Brazil, São Paulo, Silveiras, rio da Bocaina, Bairro Bom Jesus da Bocaina. Trichomycterus zonatus: FMNH 58573, 54.0 mm SL, holotype Pygidium zonatum Eigenmann, 1918, Brazil, São Paulo, rio Água 
Quente. FMNH 58574, 43.0-48.5 mm SL, 2 paratypes of Pygidium zonatum Eigenmann, 1918, São Paulo, rio Água Quente.

\section{Acknowledgements}

We are grateful to Luciano Montag and Tiago Freitas by participation in collecting the material type. We are grateful to the company AMPLO Treinamento e Consultoria for logistic support and Companhia Vale for financial support. We thank Marcelo Britto (MNRJ), Osvaldo Oyakawa (MZUSP), Leo Smith (FMNH), William Fink (UMMZ), Vinicius Abilhôa (MHNCI), Carla Pavanelli (NUPELIA), Hernán LópezFernández (ROM), and William Eschmeyer (CAS) for loans and/or permissions to access the Trichomycteridae material. We also thank Alessio Datovo by the bibliography provided. Bruno Prudente kindly assisted us with map.

\section{Literature Cited}

Arratia, G. 1998. Silvinichthys, a new genus of trichomycterid catfishes from the Argentinean Andes, with redescription of Trichomycterus nigricans. Ichthyological Explorations of Freshwaters, 9: 347-370.

Arratia, G. \& L. Huaquin. 1995. Morphology of the lateral line system and of the skin of diplomystid and certain primitive loricarioid catfishes and systematic and ecological considerations. Bonner Zoologische Monographien, 36: 1-110.

Arratia, G., A. Chang, S. Menu-Marque \& G. Rojas. 1978. About Bullochia gen. nov., Trichomycterus mendozensis n. sp. and revision of the family Trichomycteridae (Pisces, Siluriformes). Studies on Neotropical Fauna and Environment, 13: 157-194.

Bichuette, M. E. \& E. Trajano. 2004. Three new subterranean species of Ituglanis from Central Brazil (Siluriformes: Trichomycteridae). Icthyological Explorations of Freshwaters, 15: 243-356.

Bichuette, M. E. \& E. Trajano. 2008. Ituglanis mambai, a new subterranean catfish form a karst área of Central Brazil, rio Tocantins basin (Siluriformes: Trichomycteridae). Neotropical Ichthyology, 6: 9-15.

Campos-Paiva, R. M. \& W. J. E. M. Costa. 2007. Ituglanis paraguassuensis sp. n. (Teleostei: Siluriformes: Trichomycteridae): a new catfish from the rio Paraguaçu, northeastern Brazil. Zootaxa, 1471: 53-59.

Castelnau, F. L. 1855. Poissons. In: Animaux nouveaux or rares recueillis pendant l'expédition dans les parties centrales de l'Amérique du Sud, de Rio de Janeiro a Lima, et de Lima au Para; exécutée par ordre du gouvernement Français pendant les années 1843 a 1847,112 p.

Costa, W. J. E. M. \& F. A. Bockmann. 1993. Un nouveau genre néotropical de la famille des Trichomycteridae (Siluriformes: Loricarioidei). Revue Française d’Aquariologie et Herpetologie, 20: 43-46.

Datovo, A. \& M. I. Landim. 2005. Ituglanis macunaima, a new catfish from the rio Araguaia basin, Brazil (Siluriformes:
Trichomycteridae). Neotropical Ichthyology 3: 455-464.

Dingerkus, G. \& L. D. Uhler. 1977. Enzyme clearing of alcian blue stained whole small vertebrates. Stain Technology, 52: 229-232.

Fernández, L. \& M. E. Bichuette. 2002. A new cave dwelling species of Ituglanis from the São Domingos karst, central Brazil (Siluriformes: Trichomycteridae). Ichthyological Explorations of Freshwaters, 13: 273-278.

Ferraris, C. J. 2007. Checklist of catfishes, recent and fossil (Osteichthyes: Siluriformes), and catalogue of siluriform primary types. Zootaxa, 1418: 1-628.

Lundberg, J. G. \& Baskin, J. N. 1969. The caudal skeleton of the catfishes, order Siluriformes. American Museum Novitates, 2398: 1-49.

de Pinna, M. C. C. 1998. Phylogenetic Relationships of Netropical Siluriformes (Teleostei: Ostariophysi); Historical overview and Synthesis of Hypotheses, Pp. 279-330. In: L. R. Malabarba, R. E. Reis, R. P. Vari, Z. M. S. Lucena \& C. A. S. Lucena (Eds.). Phylogeny and Classification of Neotropical Fishes. Porto Alegre, Edipucrs, 603p.

de Pinna, M. C. C. \& P. Keith. 2003. A new species of the catfish genus Ituglanis from French Guyana (Osteichthyes: Siluriformes: Trichomycteridae). Proceedings of the Biological Society of Washington, 116: 873-882.

de Pinna, M. C. C. \& W. B. Wosiacki. 2003. Family Trichomycteridae (Pencil or parasitic catfishes). Pp. 270-290. In: Reis, R. E., S. O. Kullander, \& C. J. Ferraris (Orgs.). Check list of the freshwater fishes of South and Central America. Porto Alegre, Edipucrs, 729p.

Sarmento-Soares, L. M., R. F. Martins-Pinheiro, A. T. Aranda \& C. C. Chamon. 2006. Ituglanis cahyensis, a new catfish from Bahia, Brazil (Siluriformes: Trichomycteridae). Neotropical Ichthyology, 4: 309-318.

Silva, C. C. F., S. L. S. F. Matta, A. W. S. Hilsdorf, F. Langeani \& A. P. Marceniuk. 2010. Color pattern variation in Trichomycterus iheringi (Eigenmann, 1917) (Siluriformes: Trichomycteridae) from rio Itatinga and rio Claro, São Paulo, Brazil. Neotropical Ichthyology, 8: 49-56.

Tchernavin, V. 1944. A revision of some Trichomycterinae based on material preserved in the British Museum (Natural History). Proceedings of the Zoological Society of London, 114: 234-275.

Wosiacki, W. B. 2002. Estudo das relações filogenéticas de Trichomycterinae (Teleostei, Siluriformes, Trichomycteridae) com uma proposta de classificação. Unipublished Ph.D. Dissertation, Universidade de São Paulo, São Paulo. 324p.

Wosiacki, W. B. 2004. New species of the catfish genus Trichomycterus (Siluriformes, Trichomycteridae) from the headwaters of the rio São Francisco basin, Brazil. Zootaxa, 592: 1-12.

Submitted March 14, 2011 Resubmitted October 28, 2011 Accepted July 3, 2012 Published September 28, 2012 